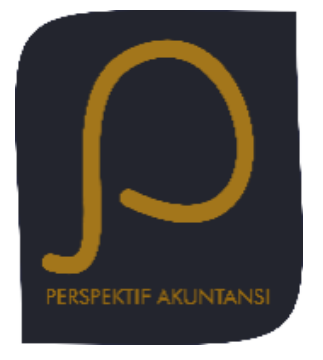

Perspektif Akuntansi

Volume 2 Nomor 1 (Februari 2019), hal. 01-18

ISSN: 2623-0194(Print), 2623-0186(Online) Copyright(C) The Authors(s). All Rights Reserved

Fakultas Ekonomika dan Bisnis,

Universitas Kristen Satya Wacana

DOI: https://doi.org/10.24246/persi.v2i1.p1-18

http://ejournal.uksw.edu/persi

\title{
CSR Expenditures, Financial Distress Prediction, and Reputation: A Pathway Analysis
}

\author{
Gavrila Adinata ${ }^{1}$ \\ International Class of Management and Accounting Program (ICMAP) \\ Faculty of Economic and Business, Satya Wacana Christian University
}

Received Abstract. This study is aimed to find the empirical evidence of the 20/12/2018 relationship between CSR expenditures and financial distress

Accepted probability of 85 Indonesian's manufacturing public company listed on BEI. A quantitative method was used to analyze the direct relationship between CSR expenditures and financial distress probability and the indirect effect of the two variables intervened by firm reputation. Observation data was obtained from each of the company's annual and financial report from the official website of BEI, particularly between the years of 2014 to 2016. Through path analysis method, the results showed that there was an insignificant positive direct relationship between CSR expenditures and financial distress probability of $4.9 \%$. The indirect effect between the two variables also showed the value of $3.7 \%$, but the relationship was rather negative. In total, an increase in one standard deviation of CSR expenditures increases the probability of a firm to be financially distressed by 1.2\%. However, with the value of $45.1 \%$, it is proven that CSR expenditures and firm reputation has a positive relationship.

Keywords: CSR expenditures, firm reputation, financial distress, Altman Z-Score, path analysis

\begin{abstract}
Abstrak. Penelitian ini bertujuan untuk menemukan bukti empiris mengenai hubungan antara pengeluaran CSR dan kemungkinan suatu perusahaan mengalami kebangkrutan (risiko kebangkrutan) dari 85 perusahaan manufaktur terbuka yang terdaftar di BEI. Metode kuantitatif digunakan untuk menganalisis hubungan langsung antara pengeluaran CSR dan risiko kebangkrutan, serta hubungan tidak langsung antara kedua variabel yang diintervensi oleh reputasi perusahaan. Data observasi diperoleh dari laporan tahunan dan laporan keuangan dari tiap perusahaan yang diambil dari situs resmi
\end{abstract}

1 232015502@student.uksw.edu 
BEI, khususnya antara tahun 2014 hingga tahun 2016. Hasil penelitian menunjukkan adanya hubungan langsung yang cenderung positif, tetapi tidak signifikan antara pengeluaran CSR dan risiko kebangkrutan sebesar 4.9\%. Hubungan tidak langsung antara kedua variabel juga menunjukkan hasil yang sebesar 3.7\%, tetapi memiliki hubungan yang cenderung negatif. Secara keseluruhan, peningkatan pada satu standar deviasi dari pengeluaran CSR perusahaan akan meningkatkan risiko kebangkrutan sebesar 1.2\%. Namun, dengan nilai sebesar $45.1 \%$, telah dibuktikan bahwa pengeluaran CSR dan reputasi perusahaan mempunyai hubungan yang positif.

Kata kunci: Pengeluaran CSR, reputasi perusahaan, kebangkrutan, Altman Z-Score, analisis jalur

\section{Introduction}

Firms and enterprises all around the globe have been battling hard to increase and show their Corporate Social Responsibility (CSR) performances. From becoming a sponsor or involving in charities, taking part in the community empowerment or environmental care, to paying more attention in health and education improvement of the surroundings and so on are the various typical forms of CSR performances. Hogan, Olson, \& Sharma (2014) highlighted Freeman's (1984) idea in which CSR is developed from the stakeholder theory. Based on the theory, firms are required to ensure the welfare of their stakeholders as one of their obligations. These stakeholders might come from inside of the firm (internal) or outside (external), and they vary from employees, customers, communities, to the environmental interests.

However, other than performing CSR, firms must also remember to keep track of their financial performance. With the involvement of mass media, excellent financial performance will ease the firm to become well-known by the communities. One advantage of this popularity is drawing customers' awareness concerning the firms' product. This will then influence the customers' decisions to buy when more customers are buying the products, the profitability increases and thus will reduce the probability of a firm to be in a financially distressed position.

Financial distress has been a significant issue to be examined as a number of large business failures, and scandals continue to emerge. To some extent, these failures and scandals are unexpectedly coming from well-known enterprises. In relation to the issues, two studies by Brooks (2016) and Al-Hadi, Chatterjee, Yaftian, Taylor, \& Hasan (2017) have found the evidence that there is a negative association between CSR expenditures and firm's probability of being financially distressed. When an enterprise experiences financial distress, it deals with an insufficient amount of cash or a tremendous amount of debt (Outecheva, 2007). 
Vilanova, Lozano, \& Arenas (2009) explicitly argued that CSR has a positive causal relationship on a firm's reputation. The firm reputation would affect the tendency of customers to buy a firm's product and thus determine the profit of a firm. Consequently, customers will be more likely to purchase a product from firms with high reputation rather than the lower ones. When a firm performs CSR activities, it ensures the welfare of their stakeholders in an exchange with an excellent reputation that may lead to higher profitability. Kanwal, Khanam, Nasreen, \& Hameed (2013) showed evidence where CSR activities enhance both reputation and profitability. Further, Gois, de Lima, de Luca, \& da Silva (2017) found that a firm's reputation has a negative causal relationship on bankruptcy risk. Another study by Casado, Yanez, \& Pelaez (2016) also found a similar finding. Thereby, these findings provide assurance that firms that contributed more in CSR would gain a better reputation. As a result, these highly reputable firms would also obtain a better opportunity to survive instead of being in a financially distressed condition.

A research conducted to examine the relationship between CSR expenditures and financial distress prediction with a firm reputation as an intervening factor is considered rare. The research by Al-Hadi et al. (2017) used firm life-cycle stages as the moderating factor, while Brooks (2016) performed a similar study with several driver factors and Goss (2009) used the degree of obligations outstanding of the firms. Accordingly, considering that CSR expenditures could reduce the probability of firms to be in a financially distressed position, particularly with a firm reputation as an intervening factor.

Based on the arguments concerning the causal relationship between CSR and financially distressed prediction, this research investigated how CSR expenditures and financial distress probability related directly or indirectly and aimed to find a direct relationship between CSR expenditures and financial distress probability and the indirect effect of the two variables intervened by the firm's reputation. This study would focus on Indonesian manufacturing company listed in BEI from 2014 until 2016. The purpose of this research is to provide empirical evidence regarding confirmation and assurance from other similar studies on the relationship between CSR expenditures and financial distress prediction of enterprises.

The next section of this research will present the literature review regarding corporate social responsibility, financial distress, and firm reputation concepts, complete with the empirical evidence that had been provided by previous academic studies. This research will also specify the research methodology used, followed by a section containing the findings and results to be discussed in order to provide the empirical evidence to answer the research questions. 


\section{Literature Review}

\section{Corporate Social Responsibility (CSR)}

In recent years, enterprises all around the world have acknowledged and taken into account CSR issues more seriously and importantly than before. They have been showing off their CSR performances to gain better reputation and image in the community. An enterprise's CSR is basically an effort to ensure the welfare of its stakeholders by contributing to social and environmental issues. Initially, it is meant to be an enterprise's "good deeds" for the surroundings in an exchange with its performed business activities, especially the activities that have the potential to harm the environment and/or bring disadvantages to the community.

After decades of relating business and society as subject to the common good concept, the 'social responsibilities' idea was finally introduced by Bowen in 1953 to the extent that a business should and could be supposed to serve the society more than what it was previously obligated (Kakabadse, Rozuel, \& LeeDavies, 2005). This is based on the many potential benefits that may come from engaging in CSR activities. Deborah et al. (2017) identified at least 3 benefits that a firm might obtain from performing CSR: arising customer loyalty, increasing employee satisfaction, and allowing the firm to get their products being differentiated by social and or environmental features. These social and environmental features are those who will benefit the society, the environment, and the end users of the products.

Many academic studies have investigated issues related to CSR to be discussed and examined. From those studies, CSR was addressed with various other terms such as Stakeholder Theory described by Freeman (1984), Corporate Social Performance (CSP) described by Waddrock \& Graves (1997), Corporate Community Involvement (CCI) described by Burk (1999), and Corporate Philanthropy as described by Godfrey (2005). Organization for Economic Cooperation and Development (OECD) (2001, p.7) defined the concept of CSR as follows:

Corporate Responsibility involves the 'fit' businesses develop with the societies in which they operate. [...] The function of business in society is to yield adequate returns to owners of capital by identifying and developing promising investment opportunities and, in the process, to provide jobs and to produce goods and services that consumers want to buy. However, corporate responsibility goes beyond this core function. Businesses are expected to obey the various laws which are applicable to them and often have to respond to societal expectations that are not written down as formal law. 
As stated by the literature, Hogan, Olson, \& Sharma (2014) stated that CSR programs involve advancing both the enterprise's and its communities' interests by donating, employee volunteering, and partnerships to develop better relationships between companies and its various stakeholders, one of them, is the customers. The relationship built from positive emotional experience results in customers' attachment to the firm's brands and believe that whatever they purchase from the firm will be returned to the communities through its CSR activities (Deborah, Love, \& Grace, 2017; Isaksson, 2012).

Excellent and comprehensive CSR programs mean that these business responsibilities are covered by enterprises: economic responsibilities, legal responsibilities, ethical responsibilities, and philanthropic responsibilities (Caroll, 1991). Hence, a company should make efforts in making a profit, complying with law and regulation, behaving ethically, and becoming a good corporate citizen to implement an acceptable CSR. The CSRHub measures and rates CSR practice and in their website (www.csrhub.com), under "The CSRHub Rating Methodology" they stated that the measurement of CSR rating might be based on how much money contributed to the communities or local charities by the enterprise. In assumption, it is based on the CSR expenditures. Based on the CSRHub statement above, this research will measure the CSR of enterprises based on their CSR expenditures of the year.

\section{Financial Distress}

Financial distress has been an important issue to be examined as a number of significant business failures, and scandals continue to emerge. To some extent, these failures and scandals were unexpectedly coming from well-known enterprises. Two studies by Brooks (2016) and Al-Hadi, Chatterjee, Yaftian, Taylor, \& Hasan (2017) found an evidence that there is a negative association between CSR expenditures and firm's probability of being financially distressed. When an enterprise experiences financial distress, it deals with an insufficient amount of cash or a considerable amount of debt (Outecheva, 2007).

In 1991, Chan \& Chen (1991, p. 1468) defined enterprises that experience marginal and financial distress as below:

They have lost market value because of poor performance, they are inefficient producers, and they are likely to have high financial leverage and cash flow problem. They are marginal in the sense that their prices tend to be more sensitive to changes in the economy, and they are less likely to survive adverse economic conditions.

Financial distress has several other terms, such as failure, default, bankruptcy, and distressed restructuring (Outecheva, 2007). The duration of financial 
distress itself might be short, or it might last permanently (O'Neill et al., 2006), and it has a characteristic in which there is a significant decline in value and performance of the enterprise (Opler \& Titman, 1994; Whitaker, 1999). Further, Outecheva (2007) described that there are four sub-intervals of financial distress; performance deterioration, failure, insolvency, and default. Performance deterioration and failure represent the profitability, while insolvency and default are subject to liquidity.

There are various methods to measure and predict financial distress based on accounting and market price. Outecheva (2007) specified that in accountingbased models, the measurement could be performed by using Beaver's Univariate Analysis of Fincanial Ratios (1966), Altman's Z-Score (1968), or Ohlson's O-Score (1980). Whereas, market-based models involve measurement by Option to Default Methodology (1974), The KMV Model (1995), or The Simple Hazard Model (2001).

This study would utilize the Altman's Z-score as the measurement method to be used in measuring enterprises' probability to experience financial distress. The Altman Z-Score is selected because it is calculated using multivariate analysis, and thereby considered as a general calculation for the financial distress prediction. While earlier study by Marcelinda, Paramu, \& Puspitasari (2014) indicates that the accuracy of the Altman Z-Score to predict bankruptcy is considered as rather low (27.96\%), other studies focused on Pakistan companies (Bashir, Javed, \& Iqbal, 2015) and Italian companies (Celli, 2015) agreed that Z-score is a valid, useful, and well-performed tool for predicting bankruptcy. In addition, the value of each variable that will be calculated in the Altman Z-Score could be easily generated from financial reports issued by the enterprises in the official website of BEI.

\section{Corporate Social Responsibility and Financial Distress Position}

Deborah et al. (2017) suggested that the intervention of a firm in the community often leads to an increase in lower turnover rates and increasing profit margins. Thus, it implies that by engaging in corporate social responsibility for the well-being of various stakeholders such as the communities, may potentially result in ensuring the business sustainability. A sustainable business means lower probability to suffer from bankruptcy. Hence, the literature argues that one benefit of engaging in CSR activities is the ability to enhance the corporate performance of the firm. This argument is supported by Caroll \& Shabana (2010) and Adegbite et al. (2012) who agree that the benefits of practicing CSR that are called as 'the business case for corporate social responsibility' serve two purposes, which are enhancing the society and creating the economic or business value of the firm. 
Brooks (2016) and Al-Hadi et al. (2017) investigated the relation between CSR and financial distress prediction. Both studies found out that there was a negative association between CSR and the probability of an enterprise to be financially distressed. Mainly, Brooks (2016) found the evidence that an increase in one standard deviation of CSR expenditures reduced the propensity of bankruptcy by 28.50 percent. He argued that investment in CSR brings tangible benefits to the enterprise. Furthermore, Goss (2009) that used CSR rankings from KLD Analytics also found the negative relationship between the two variables. Based on these arguments, this study intended to test the first hypothesis as follows:

$\mathbf{H}_{1}$ : There is a negative-direct-relationship between CSR expenditures and financial distress probability.

\section{Firm Reputation: The Intervention}

Over the years, businesses and scholars have acknowledged that reputation is one valuable intangible asset that enhances companies' competitive advantages. A firm with a good reputation will increase the shareholder value, attract more customer and high-quality staff (CIMA, 2010). However, despite a growing interest in the idea of a firm's reputation, the definition of a firm's reputation has not been completely agreed. (Barnett, Jermier \& Lafferty, 2013). Chun (2005) identified that there are three approaches that can be used to define a firm's reputation. These approaches are evaluative for financial achievement, expressional for organization impression, and relational in a different view between internal and external stakeholders. The later approach became the most used approach in many studies (Rindova, Williamson \& Petkova, 2010; Trotta \& Cavallaro, 2012; Feldman, Bahamonde, \& Bellido, 2014). The approach involves multiple stakeholder views as comparisons that can provide aggregate and collective measures.

In 2007, Guy Jubb, the Head of Corporate Governance at Standard Life Investment (UK) was interviewed by Brady and Honey, and he remarked a firm's reputation as: "a concept embodied the image and values of a company and was therefore intimately linked with the concept of corporate responsibility." This is strengthening the argument that there is indeed a linkage between firm reputation and CSR. Deborah et al. (2017) also argued that the intervention of a firm to engage in CSR that is enhancing its communities often results in increasing the image and the reputation of the firm.

Firms are engaging in CSR in an exchange with a better reputation from the society, and this reputation might bring certain financial and non-financial benefits to the firms. Deborah et al. (2017) identified that one benefit of performing CSR activities is that it may potentially increase customer loyalty 
from the relationship built. However, Hawkins (2006) argued that the objective of CSR is to build a more sustainable business operation of a firm and then promote it to attract customers and consumers. Based on this argument, CSR allows the firm to arise its consumers' awareness for their products or brands. In order to raise awareness, some firms might find it necessary to improve their marketing strategy, engage in CSR programs, or win some awards.

The first two ways could often be easily recognized by the firms but it might not for the later. In this digital era where information could be easily obtained from anywhere around the globe, a rewarding achievement would attract the media to report it to the public by writing a news release. This news would then be spread, and so on, the society would recognize the firm for being good enough to win an award. Thus, winning an award could be advantageous to improve social awareness, and at the same time, the firm is actually building a good reputation. When society is aware of the products or brands, they will be more likely to purchase from the firms and thus increase the profitability of the firms that can help the firms avoid bankruptcy. Argumentatively, the second hypothesis of this research is formulated as the following:

$\mathbf{H}_{2}$ : There is a negative-indirect-relationship between CSR expenditures and financial distress probability.

Figure 1 shows the conceptual framework regarding the direct relationship between CSR Expenditure with the Altman Z-score, and through firm reputation.

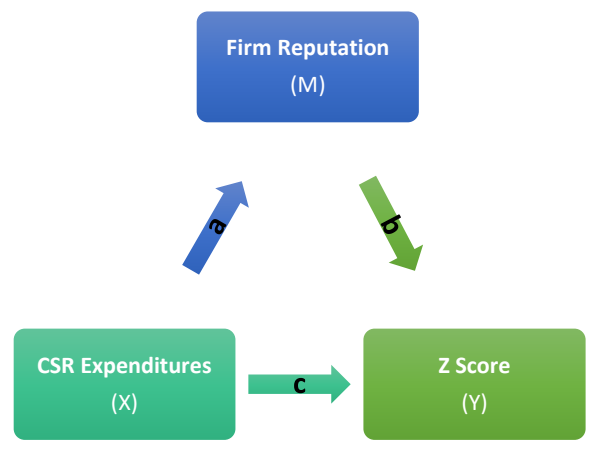

Figure 1. The Path Model

\section{Research Methods}

\section{Type and Source of Data}

This research is aimed to collect empirical evidence of the direct and indirect relationship between corporate social responsibility expenditures and financial distress prediction by using the firm's reputation as the intervening factor 
between the two variables. This study will use quantitative data from the annual and financial reports of firms that are classified under the manufacturing sector during the 2014-2016 period. The secondary data used are taken from the Indonesian Stock Exchange (IDX) official website on www.idx.co.id and also from each firm's official websites, depending on the necessity.

\section{Population and Sample}

The population in this research is all firms listed under the manufacturing sector between 2014-2016 on BEI. Purposive sampling technique is used to select the samples, with the criteria specified as follows: (1) Manufacturing firms that are listed in the IDX on the base year of 2014; (2) Firms which provide accessible annual (financial) reports for 2014-2016; (3) Firms that have published complete annual (financial) reports from 2014-2016; (4) Firms which have been performing CSR regularly during 2014-2016; (5) Firms that are disclosing their CSR expenditures or professional/consultant fees in the annual (financial) reports of the observed years.

The sampling process of this research is outlined in Table 1 below:

\section{Table 1. Sampling Process Outline}

\begin{tabular}{lc}
\hline \multicolumn{1}{c}{ Purposive Requirements } & $\begin{array}{c}\text { Number of } \\
\text { Companies }\end{array}$ \\
\hline Manufacturing firms that listed in the IDX on the base year of 2014 & 143 \\
Firms with no accessible annual (financial) reports for 2014-2016 & $(32)$ \\
Firms with incomplete annual (financial) report from 2014-2016 & $(16)$ \\
Firms which are not performing CSR regularly during 2014-2016 & $(5)$ \\
Firms that are not disclosing their CSR expenditures explicitly or & $(5)$ \\
implicitly & 85 \\
\hline Final sample firms & 255 \\
\hline
\end{tabular}

Source: Secondary data

\section{Variables Description}

Endogenous variables are variables which are having arrows towards them. In the path analysis, endogenous variables include the mediating (intervening) variable and the dependent variable (Sarwono, 2007). The dependent variable $(\mathrm{Y})$, which is later called as an endogenous variable of this research is the financial distress prediction or bankruptcy risk based on the Altman Z-Score founded in 1968. Altman Z-Score is a multivariate discriminant analysis tool to categorized between distressed and non-distressed enterprises. This score is calculated by combining up five different ratios, to form an overall score of an enterprise's financial health prediction. A cut-off score that separate distressed and non-distressed groups are specified as 2.67. Enterprises that have a lower 
score than the cut-off score are categorized as distressed firms and vice versa. Outecheva (2007) thereby stated that the lower the Z-Score, the higher is the potential of an enterprise to go bankrupt. Thus, the score can be calculated by using the function as specified below (Outecheva, 2007):

$\mathrm{Z}=0.717 \mathrm{X}_{1}+0.847 \mathrm{X}_{2}+3.107 \mathrm{X}_{3}+0.420 \mathrm{X}_{4}+0.998 \mathrm{X}_{5}$

where: $Z$ = Altman's overall score, $X_{1}=$ working capital to assets, $X_{2}=$ retained earnings to total assets, $X_{3}=$ earnings before interest and taxes (EBIT) to total assets, $X_{4}=$ market value of equity to book value of total liabilities, and $X_{5}=$ sales to total assets.

The exogenous variable is variable which is not having any arrow towards it (Sarwono, 2007). CSR expenditures as the independent variable (X), or later called as an exogenous variable of this research are the amount of money that firms contributed during a one-year period to perform their CSR activities. Usually, the source of this fund is from the firms' reserves on previous year's net income. Thus, when a firm is experiencing loss in the previous year, it will be less likely to perform CSR activities in the next year due to an insufficient amount of allowance. The value of CSR expenditures can be seen on the firms' annual reports, but it has been known that most firms didn't state the amount while selecting the sample firms.

Also, while selecting samples, it is found that mostly, firms are stating the amount of CSR expenditures only by means of approximating. A book by Hohnen (2007) specified a process of identifying and engaging stakeholders while implementing CSR. Accordingly, firms use one of the many independent consultants specialized in mapping stakeholders to help with this or other CSR processes. Thus, another parameter of measuring CSR expenditure would use the number of professional fees and or consultation fees outside the fees specified in the business operation that is paid by the company. This measurement is assuming that when a firm is implementing a CSR, it might first require the help from CSR professionals for consultation. The amount of this professional and consultation fees will then be totaled with the original, specified CSR expenditures if any.

An intervening variable is a variable that explains the relationship between other variables. In the analysis, later this variable will also be called as an endogenous variable along with the dependent variable. The firm's reputation is becoming the intervening variable of this research because it is considered an indirect linking factor that relates the CSR expenditures as the independent variable and the probability of bankruptcy as the dependent variable. Firms which won an award are improving the social awareness and building a good reputation. Based on this argument, the measurement of firm reputation 
variable would be based on the number of awards a firm received on each of the observed years. The number of awards will then be compared with the accumulation of an overall number of awards received by all observed firms during three consecutive years $(2014,2015$, and 2016) to form a reputation index.

\section{Data Analysis Technique}

In order to be able to test the hypothesis of this research, several data analysis prerequisite tests need to be done. The tests involve a normality test, linearity test, and test for autocorrelation (Olobatuyi, 2006). The result shows the $\mathrm{R}$ square $\left(R^{2}\right)$ value of 0.034 . With the sample size $(\mathrm{N})$ of 240 , the value of $\mathrm{c}^{2}$ count is $8.16(0.034 \times 240)$. Whereas, the value of $c^{2}$ table with the Degree of freedom (Df) of 237 (240-3) and a significant level of 0.05 is 273.91 . Since the value of $\mathrm{C}^{2}$ count is less than the value of $\mathrm{c}^{2}$ table, then it can be concluded that the proposed model has a linear association.

After meeting the linearity test, the test for autocorrelation could be performed. This test is meant to make sure that there is no autocorrelation between the variables themselves, which is usually happening in time series data just like the data being used in this research. The test is conducted using Runs Test. Runs test is performed to see the randomness of the residual. A random residual means that there is no autocorrelation problem (Asymp Sig. $\geq 0.05$ ). The result indicates that there is no autocorrelation problem $(0.301>0.05)$.

Since there is an intervening variable used in this research (firm reputation), the relationship between the variables is tested by using path analysis model developed by Sewall Wright in 1921. The model is an extension of multiple regression and is referred to as causal modeling to uncover causal pathways between variables (Streiner, 2005). Pathway analysis or multiple regression with an intervening variable is aimed to uncover both the direct effect ( $\mathrm{X}$ to $\mathrm{Y}$ ) and indirect effect ( $\mathrm{X}$ to $\mathrm{Y}$ through $\mathrm{M}$ ) to calculate the total effect of the model proposed (Ghozali, 2017).

\section{Table 2. Regression Equations}

\begin{tabular}{ll}
\hline Analysis & Equations \\
\hline Simple regression for predicting $X$ to $M$ (path a) & $\mathrm{M}=\mathrm{B}_{1} \mathrm{X}+\mathrm{e} 1$ \\
Multiple regression for predicting $\mathrm{X}$ and $\mathrm{M}$ to $\mathrm{Y}$ (path b and c) & $\mathrm{Y}=\mathrm{B}_{1} \mathrm{X}+\mathrm{B}_{2} \mathrm{M}+\mathrm{e} 2$ \\
\hline
\end{tabular}

The value of $\mathrm{e} 1\left(\mathrm{e} 1=\sqrt{1-R^{2}}\right)$ shows the variance variables of firm reputation that could not be explained by the CSR expenditures. Meanwhile, the variance variables of Z-Score that could not be explained by both firm reputation and CSR expenditures are shown by the e 2 value $\left(\mathrm{e} 2=\sqrt{1-R^{2}}\right.$ ). From the model, the regression equations can be formulated and tested step by step as specified in the Table 2 . 


\section{Results and Discussions}

The following Table 2 shows the descriptive statistics of all 255 observed firms' data. The CSR expenditures of observed firms varied from just about 20 million (Rp23.791.300) up to almost two trillion Rupiah (Rp1.938.000.000.000). For the firm reputation, the highest number of awards achieved by a firm in one observation year are 104 awards. Respectively, a firm could win no award at all. While the Z-score represented by all observed firms shows that there is 160 firms' data with high financial distress probability and only 95 of the data had low probability to be in a financially distressed position. Accordingly, there is only $37.2 \%$ of the observed firms' data that are in an adequate condition to make them have a higher probability to avoid bankruptcy.

Table 3. Variable Description

\begin{tabular}{llll}
\hline Variables & Minimum & Maximum & Standard Deviation \\
\hline CSR Expenditures (Lg10) & 7.38 & 12.29 & 0.8290 \\
Firm Reputation & 0.00 & 0.08 & 0.0087 \\
Z-Score & -10.00 & 8.72 & 1.9851 \\
\hline
\end{tabular}

Source: Secondary data

In this study, the Path Analysis is used to obtain both the direct ( $\mathrm{X}$ to $\mathrm{Y}$ ) and indirect effect ( $\mathrm{X}$ to $\mathrm{Y}$ through $\mathrm{M}$ ) between the variables. By knowing the direct and indirect effect between the variables, the total effect of the model being proposed could be calculated (Ghozali, 2017). The effect is known as the path coefficient represented in the standardized beta coefficients of the two regressions models.

The summary of the result for the impact of CSR expenditures on the firm's reputation (path a), which is the first regression model, could be seen in Table 4. The table shows the CSR expenditures as an exogenous variable and the firm reputation as the endogenous variable.

Table 2. Summary Result

\begin{tabular}{llll}
\hline & & Reputation & Sig. \\
\hline \multirow{3}{*}{ CSR Expenditures } & F & 60.690 & 0.000 \\
& Beta & 0.451 & 0.000 \\
& R Square & 0.203 & \\
\hline
\end{tabular}

Source: Secondary data

In Table 4 above, the beta coefficient value of 0.451 is the value of path a. A significance level of 0.000 (less than 0.05 ) indicates that CSR expenditures significantly affect the firm's reputation and the relationship is slightly positive. In other words, an increase of one standard deviation of CSR expenditures would increase the firm's reputation by $45.1 \%$. The R square value of 0.203 will 
be used to calculate e1, which is the variance variables of the firm's reputation that could not be explained by CSR expenditures.

Table 5 shows the research result of the second regression model for the effect of CSR expenditures and Firm Reputation each to the Z-Score.

Table 3. CSR Expenditures and Firm Reputation to the Z-Score

\begin{tabular}{|c|c|c|c|}
\hline & & Z-Score & Sig. \\
\hline CSR Expenditures & & -0.049 & 0.501 \\
\hline Reputation & Deta & 0.083 & 0.252 \\
\hline $\mathrm{F}$ & & 0.674 & 0.510 \\
\hline R Square & & 0.006 & \\
\hline
\end{tabular}

Source: Secondary data

This research aimed to seek evidence on the direct and indirect relationship between CSR expenditures and financial distress probability. To test the first hypothesis $\left(\mathrm{H}_{1}\right)$, the direct effect between CSR Expenditures and Z-Score could be seen in the value of path $c$, with a beta coefficient of -0.049 . This value indicates that a greater CSR Expenditures will lower the value of Z-Score, but not significant. Despite, an increase in CSR expenditures will lower the Z-score value by $4.9 \%$.

The lower value of Z-Score means a higher probability of financial distress. Thus, an increase in one standard deviation of CSR expenditures will increase the probability of a firm to be in a financially distressed position by $4.9 \%$. It means that the direct relationship between CSR expenditures and financial distress probability is instead on the positive side. Therefore, the first hypothesis $\left(\mathrm{H}_{1}\right)$ of this research is not proven. This result is not in line with the proposed first hypothesis $\left(\mathrm{H}_{1}\right)$ which is supported by Al-Hadi et al. (2017), Brooks (2016), and Goss (2009) where investment in CSR will have a negative relationship with the financial distress probability. This result is possible because of the difference in the method used to measure the financial distress probability.

As stated in the literature review, there are various measures on predicting bankruptcy besides the Altman Z-Score. Although, the Altman Z-Score method involves multivariate analysis, unfortunately, the effectiveness of Altman ZScore to predict bankruptcy is questionable for this study. This could be because the Altman Z-Score might not relevant for the present condition. Hence, other measures founded recently such as the KMV Model or the Simple Hazard Model might provide more relevant output.

With the R square value of 0.006 , the value of e2 is $0.997(\sqrt{(1-0.006})$. This value of e 2 means that there is $99.7 \%$ possibility that there are other variables that could explain the Z-Score besides the CSR expenditures. Despite the fact 
that the Altman Z-Score is indeed a multivariate analysis for predicting bankruptcy, the measurement includes ratios that are not statistically significant related to the amount CSR expenditures.

To test the second hypothesis $\left(\mathrm{H}_{2}\right)$, the indirect effect of CSR Expenditures to the Z-Score through firm reputation could be calculated by multiplying the coefficient of path a and path $b(0.451 \times 0.083)$. Hence, the value of the indirect effect is 0.037 . The insignificant value of indirect effect means that an increase in CSR expenditures will result in a higher value of Z-score by 3.7\%. Higher Zscore value means lower probability to be financially distressed. Thus, an increase in one standard deviation of CSR expenditures will lower the probability of a firm to be in a financially distressed position by $3.7 \%$. By this result, the second hypothesis is proven and could be accepted.

With the direct effect of -0.049 and indirect effect of 0.037 , then the total effect of the proposed model is $-0.049+0.037=-0.012$. The value of the total effects indicates that there is a negative relationship between CSR expenditures and ZScore that are proposed in the model. An increase in one standard deviation of CSR expenditures resulted in a lower Z-score value by $-1.2 \%$. Lower Z-Score value means a higher probability of financial distress.

Figure 2 below shows the path model along with the value of path coefficients known from performing regressions for testing the model.

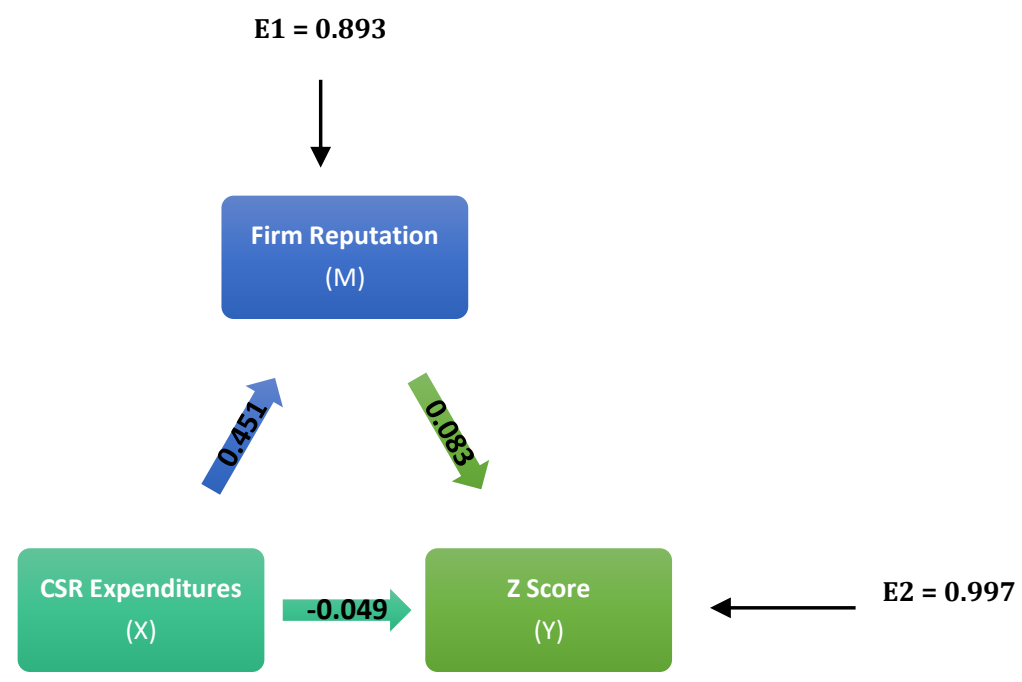

Figure 2 Result of Path Model Testing

Accordingly, there is a positive relationship between CSR expenditures and financial distress probability, where an increase in one standard deviation of CSR expenditures increase the probability of a firm to be financially distressed by $1.2 \%$. This strengthens the results of Marcelinda, Paramu, \& Puspitasari 
(2014) study that states the accuracy of Altman Z-Score to predict bankruptcy is only $27.96 \%$, and a contradictive with the study of Bashir, Javed, \& Iqbal (2015) and Celli (2015) who agreed that the Altman Z-Score is considered as a valid, useful, and well-performed tool for predicting bankruptcy.

The results of the research could not provide statistically significant value that shows directly, an increase in one standard deviation of CSR expenditures will increase the probability of a firm to be in a financially distressed position by $4.9 \%$. Indirectly, an increase in one standard deviation of CSR expenditures will lower the probability of a firm to be in a financially distressed position by $3.7 \%$. Also, by using the proposed path model, there is a positive relationship between CSR expenditures and financial distress probability, where an increase in one standard deviation of CSR expenditures increase the probability of a firm to be financially distressed by $1.2 \%$.

Once again, both of the results show insignificant value. This means that the proposed path model is proven as failed to reveal the causal pathways between CSR expenditures and financial distress probability. The failure could be seen clearly from the value of 1 which indicates that there are $89.3 \%$ other variables influencing the firm's reputation except for CSR expenditures. The value of e2 which indicates that Z-Score is $99.7 \%$ influenced by other variables besides CSR expenditures and the firm's reputation.

\section{Conclusions}

The result is not statistically in accordance with the proposed first hypothesis of this research, while the second hypothesis is statistically accepted. The relationship between CSR expenditures and the firm's reputation shows the possible significant positive relationship. However, when each of CSR expenditures and firm reputation is related with the Z-score, the coefficient relationship becomes insignificant. Under these results, this research concludes that there is a possibility that the Z-Score could not capture the probability of bankruptcy. The insignificant value of the results might be because of the various method of measuring the probability of financial distress were the chosen method, the Altman Z-Score is not possibly not suitable this study.

There are several limitations to this study, first, some of the observed firms are identifying the amount of CSR expenditures only by means of approximating and some firms are mixing up the professional fees account with another account in the report with no specified notes about the allocation for each. Second, the research found that there are firms which are not explicitly stating the year in which they achieved an award. These two limitations could potentially lead to less accurate data collection. Third, this research is limited 
to investigate the sample manufacturing firms listed on IDX regardless of the proportion of the sub-sector division of each firm that may affect the extent of the research result being generated.

This study suggests that the future research could generate CSR expenditures and the firm's reputation data by taking only firms which precisely and accurately provide the amount of CSR expenditures and achieved awards to gain more accurate results. In addition, future studies may consider taking sample firms in a proportional manner from each of the sub-sector divisions to provide more in-depth and detailed results to get a picture of each different condition. Finally, regarding the potentially ineffective financial distress probability measurement, the future research could choose another method for predicting bankruptcy which is more up-to-date, such as the KMV Model (1995), the Simple Hazard Model (2001), or by comparing different models to find out a consistent result adequate for concluding whether a firm has a probability to be financially distressed or not.

\section{References}

Adegbite, A., Amiolemen, S., Ologeh, I., \& Oyefuga, I. (2012). Sustainable Development Policy and Corporate Social Responsibility in Business Organizations in Nigeria. Journal of Sustainable Development, 5(6).

Al-Hadi, A., Chatterjee, B., Yaftian, A., Taylor, G., \& Hasan, M. (2017). Corporate Social Responsibility Performance, Financial Distress, and Firm Life Cycle: Evidence from Australia. Journal of Accounting and Finance.

Barnett, M., Jermier, J., \& Lafferty, B. (2013). Corporate Reputation: The Definitional Landscape. Palgrave Macmillan Journal, 9(1).

Bashir, A., Javed, A., \& Iqbal, S. (2015). Business Failures Prediction in Karachi Stock Exchange. Indian Journal of Management Science, 5(1).

Brooks, L. Z. (2016, April 30). Can Corporate Social Responsibility Reduce the Propensity of Future Bankruptcy? SSRN. Retrieved February 4, 2017, from SSRN: https://papers.ssrn.com/sol3/papers.cfm?abstract_id=2812669

Burk, E. (1999). Corporate Community Relations: The Principle of the Neighbor of Choice. Westport: CT. Preager.

Caroll, A. B. (1991). The Pyramid of Corporate Social Responsibility: Toward the Moral Management of Organizational Stakeholders. Business Horizons, 39-48.

Caroll, A., \& Shabana, K. (2010). The Business Case for Corporate Social Responsibility: A Review of Concepts, Research, and Practice. International Journal of Management Reviews, 12(1).

Casado, A., Yanez, E., \& Pelaez, A. (2016). The Value of Corporate Reputation in the Bankruptcy Risk. Journal on Systemics, Cybernetics, and Informatics.

Celli, M. (2015). Can Z-Score Model Predict Listed Companies Failures in Italy? An Empirical Test. International Journal of Business and Management, 10(3).

Chan, K., \& Chen, N.-F. (1991). Structural and Return Characteristics of Small and Large Firms. Journal of Finance, 46(4), 1467-1484.

Chun, R. (2005). Corporate Reputation: Meaning and Measurement. International Journal of Management Reviews, 7(2). 
CIMA. (2010). Corporate Reputation: Perspectives of Measuring and Managing Principal Risk. London: CIMA.

CSRHub. (n.d.). CSRHUB: Sustainability Management Tools. Retrieved February 3, 2017, from https://www.csrhub.com/content/csrhub-ratings-methodology/

Deborah, M. B., E.K., W. R., Love, M. C., \& Grace, A. C. (2017). Corporate Social Responsibility as a Determinant of Sustainability of Small Medium Enterprises (SMEs). Covenant Journal of Business \& Social Sciences (CJBSS), 8(2).

Feldman, P., Bahamonde, R., \& Bellido, I. (2014). A New Approach For Measuring Corporate Reputation. Real Academica Espanola, 54(1).

Freeman, R. E. (1984). Strategic Management: A Stakeholder Approach. Boston: Pitman.

Ghozali, I. (2017). Aplikasi Analisis Multivariate dengan Program SPSS (8 ed.). Semarang: Badan Penerbit Universitas Diponegoro.

Godfrey, P. (2005). The Relationship between Corporate Philanthropy and Shareholder Risk: A Risk Management Perspective. Academy of Management Review, 30, 777-798.

Gois, A., de Lima, G., De Luca, M., \& da Silva, E. (2017). The Effect of Corporate Reputation on Market Risk and Bankruptcy Risk. Journal of International Accounting Research.

Goss, A. (2009). Corporate Social Responsibility and Financial Distress. Administrative Sciences Association of Canada (ASAC).

Hawkins, D. E. (2006). Corporate Social Responsibility - Balancing Tomorrow's Sustainability and Today's Profitability. Palgrave Macmillan.

Hogan, K., T. Olson, G., \& Sharma, R. (2014). The Role of Corporate Philanthropy on Ratings of Corporate Social Responsibility and Shareholder Return. Journal of Leadership, Accountability and Ethics, 11(3), 108-125.

Hohnen, P. (2007). Corporate Social Responsibility: An Implementation Guide for Business. Winnipeg: International Institute for Sustainable Development.

Isaksson, L. (2012). Corporate Social Responsibility: A Study of Strategic Management and Performance in Swedish. Goldcoast. Queensland: Bond University. Retrieved November 9, 2018, from http://epublications.bond.edu.au/th eses/68/

Kakabadse, N. K., Rozuel, C., \& Lee-Davies, L. (2005). Corporate Social Responsibility and Stakeholder Approach: A Conceptual Review. International Journal of Business Governance and Ethics, 1(4), 277-302.

Kanwal, M., Khanam, F., Nasreen, S., \& Hameed, S. (2013). Impact of Corporate Social Responsibility on the Firm's Financial Performance. IOSR Journal of Business and Management.

Marcelinda, S. O., Paramu, H., \& Puspitasari, N. (2014). Analysis of the Accuracy of Altman Z-Score Bankruptcy Prediction Model in Manufacturing Companies Listed in Indonesia Stock Exchange. e-Journal Ekonomi Bisnis dan Akuntansi, $1(1)$.

OECD. (2001). Corporate Responsibility: Private Initiatives and Public Goals. Paris: OECD.

Olobatuyi, M. E. (2006). A User's Guide to Path Analysis. Lanham, Maryland: University Press of America Inc.

O'Neill, B., Sorhaindo, B., Prawitz, A., Kim, J., \& Garman, E. (2006). Financial Distress: Definition, Effects, and Measurement. Consumer Interests Annual, 52, 1-8.

Opler, T., \& Titman, S. (1994). Financial Distress and Corporate Performance. Journal of Finance, 49(3), 1015-1040.

Outecheva, N. (2007). Corporate Financial Distress: An Empirical Analysis of Distress Risk. Bamberg: Difo-Druck GmbH.

Rindova, V., Williamson, I., \& Petkova, A. (2010). Reputation as an Intangible Assets: Reflections on Theory and Methods in Two Empirical Studies of Business School Reputation. Journal of Management, 36(3). 
Sarwono, J. (2007). Analisis Jalur untuk Riset Bisnis dengan SPSS. Yogyakarta: CV Andi Offset.

Streiner, D. (2005). Finding Our Way: An Introduction to Path Analysis. The Canadian Journal of Psychiatry, 50(2).

Trotta, A., \& Cavallaro, G. (2012). Measuring Corporate Reputation: A Framework for Italian Banks. International Journal of Economics and Finance Studies, 4(2).

Vilanova, Marc \& Lozano, Josep \& Arenas, Daniel. (2008). Exploring the Nature of the Relationship Between CSR and Competitiveness. Journal of Business Ethics. 87. 57-69. 10.1007/s10551-008-9812-2.

Waddrock, S., \& Graves, S. (1997). The Corporate Social Performance-Financial Performance Link. Strategic Management Journal, 18, 303-319.

Whitaker, R. (1999). The Early Stages of Financial Distress: Bankruptcy Costs and the New Bankruptcy Code. Journal of Finance, 23(2), 123-133. 